\title{
Aggregation stability and organic carbon fraction in a soil amended with some plant residues, nanozeolite, and natural zeolite
}

\author{
Milad Mirzaei Aminiyan • Ali Akbar Safari Sinegani • \\ Mohsen Sheklabadi
}

Received: 12 August 2014/ Accepted: 1 December 2014/Published online: 10 December 2014

(C) The Author(s) 2014. This article is published with open access at Springerlink.com

\begin{abstract}
This research is aimed to study comparison of the effects of applied nanozeolite and zeolite on aggregation and organic carbon (OC) in each aggregate size fraction in treated soil with different levels of some plant residues and incubation for 90 days. The analysis of variance showed that the effects of applied nanozeolite, zeolite, plant residues, and their interaction and incubation times on MWDw and OC in aggregate size fractions were statistically significant. The results showed that MWDw and OC contents in each aggregate size fraction increased with the additions of nanozeolite, zeolite, and plant residues. This study also revealed that nanozeolite and alfalfa straw were more effective for increasing the MWDw and OC contents in aggregate size fractions than zeolite and wheat straw, respectively. In other words, higher percentage nanozeolite, zeolite, and plant residues resulted in increasing the MWDw and OC in aggregate size fractions. The highest amounts of OC were observed in A and B compounds compared with the control and other treatments. However, the comparison of OC contents in all the treatments showed that proportion of nanozeolite for increasing the OC content was greater than that of zeolite. Also the highest $\mathrm{OC}$ contents were observed in larger aggregate size fractions. The MWDw and OC contents increased with the increasing days of incubation in treated soil. Thus, it was
\end{abstract}

M. Mirzaei Aminiyan $(\bowtie)$ · A. A. Safari Sinegani .

M. Sheklabadi

Soil Science Department, College of Agriculture, Bu-Ali Sina University, Azadegan Street, 6517833131 Hamedan, Iran e-mail: miladmir67@yahoo.com

A. A. Safari Sinegani

e-mail: safari_sinegani@yahoo.com

M. Sheklabadi

e-mail: sheklabadi@yahoo.com concluded that compound A can be more effective to improve the soil carbon sequestration.

Keywords Nanozeolite $\cdot$ Zeolite $\cdot$ Plant residue $\cdot$ Organic carbon $\cdot$ Aggregation $\cdot$ Incubation

\section{Introduction}

Aggregation has a major effect on carbon cycling in soil. Aggregates are composed of primary mineral particles and organic binding agents (Haynes and Swift 1990; Tisdall and Oades 1982). Soil aggregation and soil structure are important aspects of soil fertility in influencing the root distribution and the uptakes of water and nutrients (Pachepsky and Rawls 2003; Bronick and Lal 2005). The initial unit of aggregation is called microaggregate. According to Tisdall and Oades (1982), the microaggregates $(<0.25 \mathrm{~mm})$ are bounded together by organic compounds of different origins to form macroaggregates $(>0.25 \mathrm{~mm})$.

The macroaggregates affect soil carbon storage by occluding organic residues, making them less accessible to degrading organisms and their enzymes (Six et al. 2000). The soil organic carbon (SOC) protection by aggregates has been extensively studied (Tisdall and Oades 1982; Elliott 1986; Gupta and Germida 1988; Angers 1992). Christensen (2001) considered the structural control of soil aggregates as the accessibility of decomposers for the SOC, diffusion of oxygen, degradation of products, transport of moisture, etc. Beare et al. (1994) showed that macroaggregates $(>0.25 \mathrm{~mm})$ in nontilled soils provide an important mechanism for the SOC protection. Six et al. (2002) asserted that SOC protection is greater within free microaggregates $(<0.25 \mathrm{~mm})$ than within macroaggregates. 
Carter et al. (2003) concluded that macroaggregates play an important role in the SOC storage, although protection by macroaggregates is labile because macroaggregates provide an environment conducive for interactions between clay particles and the SOC. Even though the effect of the SOC on soil aggregation seems to be more evident in the wet-sieved aggregates (Puget et al. 2000), the aggregates obtained from dry sieving might have more information on the processes occurring in situ. Previous studies of these sites between 1995 and 2002 showed that tillage practices influenced the accumulation of the SOC fractions (Wander and Bidart 2000; Yoo and Wander 2008).

Soil aggregation, more specifically of macroaggregates $(250-2,000 \mu \mathrm{m})$ and microaggregates $(53-250 \mu \mathrm{m})$, has direct influence on soil properties such as, but not limited to, bulk density, pore size distribution (Hillel 1982), microbial community structure (Paul and Clark 1996), and soil resistance to erosion (Valmis et al. 2005). Soil organic matter (SOM) indirectly contributes to soil structure by serving as a nucleus for aggregate formation (Six et al. 1998). SOM has been found to increase with reclamation age, but there is not always a corresponding increase in soil macroaggregation (Malik and Scullion 1998).

The fractionation of water-stable aggregates and density fractionation may thus be helpful for an improved understanding of carbon dynamics affected by soil management, since aggregate and density fractions are more sensitive to changes in soil management than total OC (Oades 1988; Pikul et al. 2007; Puget et al. 2000; Von Lützow et al. 2006). For example, Puget et al. (2000) concluded that water-stable macroaggregates were enriched in younger organic materials and have faster turnover times than microaggregates. Meanwhile, it is currently ascertained that the quality of organic matter is involved in both the accumulation of OC and the stabilization of soil particle sizes and aggregates (Piccolo et al. 2004; Spaccini et al. 2002; Yamashita et al. 2006).

Organic matter inputs through organic amendment, in addition to supplying nutrients, improve soil aggregation, and stimulate microbial diversity and activity (Shiralipour et al. 1992; Carpenter-Boggs et al. 2000). Soil aggregate stability is important for carbon (C) sequestration (Chivenge et al. 2011; Laganière et al. 2011). Soil microaggregates (i.e., organo-mineral complexes) form through the interaction of clay colliding with organic compounds and inorganic cementing materials (BlancoCanqui and Lal 2004). Macroaggregates are composed of microaggregates bonded by root hair and fungal hyphae (Oades. 1984; Shukla et al. 2004). Natural zeolites are extensively used to improve soil physical environment, particularly, in sandy and clay poor soils (Abdi et al. 2006). The purpose of this study was to compare the effects of nanozeolite and zeolite on mean weight diameter of water-stable (MWDw) aggregates and OC in each fraction of MWDw in a treated soil by some plant residues.

\section{Materials and methods}

\section{Site description}

This study was conducted in Hamedan province, western part of Iran. This area is located between longitudes $47^{\circ} 42^{\prime}$ and $48^{\circ} 45^{\prime} \mathrm{E}$ and latitudes $33^{\circ} 28^{\prime}$ and $34^{\circ} 29^{\prime} \mathrm{N}$. The climate of the region is semiarid with a mean annual precipitation of $300 \mathrm{~mm}$ and a mean annual temperature of $10^{\circ} \mathrm{C}$. Agriculture is an industry and constitutes principal land use in Hamadan. Major crops grown in Hamadan are winter wheat (Triticumaestivum L.), Alfalfa (Medicago sativa), potato (Solanumtubersum), and garlic (Allium sativum). The soil of this area is mostly classified as typic Haplocalcids.

Sampling, treatment, and analysis of soil

The soil samples were collected from the top layer of soil $(30 \mathrm{~cm})$ from an agricultural land. Wheat straw, alfalfa straw, nanozeolite $\mathrm{pH}$, and electrical conductivity (EC) were measured in a 1:10 soil, plant residues, and nanozeolite separately: water extract after shaking for $2 \mathrm{~h}$. Their OCs were measured by wet oxidation (Walkley and Black 1934). The total phosphorous (P) was measured in an acidic $(\mathrm{HCl})$ solution of ashes of plant residues spectrophotometrically as blue molybdatephosphate complexes under partial reduction with ascorbic acid (Peperzak et al. 1959). The total nitrogen (N) content was measured by the Kjeldahl method (Hinds and Lowe 1980). Cation exchange capacity (CEC) of the soils were determined by the $1 \mathrm{M} \mathrm{NaOAc}$, pH 8.2 method (Pratt 1965). Subsequently, the soil was then air dried and mixed with different amounts of $(d<2 \mathrm{~mm})$ wheat straw and alfalfa straw (0 and $5 \%$ w/w) separately; afterward, the samples were mixed with different amounts of nanozeolite $(0,10$, and $30 \% \mathrm{w} / \mathrm{w})$ and then were kept in field capacity moisture content and lab condition.

Untreated soils were also incubated as controls. The treated soils, wheat straw, alfalfa straw, and nanozeolite were uniformly wetted with a spray to a water content near field capacity. The approximate field capacity of each mixture of soil, wheat straw, alfalfa straw, and nanozeolite was measured gravimetrically, and the volume of water required to bring each of the soils to the approximated field capacity was determined by weighing daily. The treated and moistened soils were incubated in lab condition 
$\left(20-25{ }^{\circ} \mathrm{C}\right)$ for 90 days. After $1,5,10,20,30,45,60,75$, and 90 days of incubation, a portion of each soil was taken for the study of MWDw and its OC fractions.

\section{Aggregate fractionation}

The classical procedure described by Kemper and Rosenau (1986) was used to separate water-stable aggregates. In brief, $20 \mathrm{~g}$ of $<4 \mathrm{~mm}$ air-dried soil samples was put on the topmost sieve of a nest of three sieves of $2,1,0.25$, and $0.053-\mathrm{mm}$ mesh sizes and pre-soaked in distilled water for $30 \mathrm{~min}$. Then, the nest of sieves was oscillated vertically in water 20 times, using a $4-\mathrm{cm}$ amplitude at the rate of one oscillation per second. Care was taken to ensure that soil particles on the topmost sieve were always below the water surface during each oscillation. After wet sieving, the water-stable soil materials left in each sieve were quantitatively transferred into beakers, dried in the oven at $50{ }^{\circ} \mathrm{C}$ for $48 \mathrm{~h}$, weighed, and stored for later analysis. OC content in each fraction was measured by Walkley and Black (1934) method. MWDw was calculated by the following equation:

$\mathrm{MWDw}=\sum_{i=1}^{n}\left(X_{i} \cdot W_{i}\right)$

where $X_{i}$ is the mean diameter of the ith sieve, and $W_{i}$ is the amount of total aggregates in ith fraction.

Statistical data analysis

The experiment was a complete randomized factorial design with three replicates. The factors applied were alfalfa straw (0 and $5 \% \mathrm{w} / \mathrm{w})$, wheat straw (0 and $5 \%$ $\mathrm{w} / \mathrm{w})$, Nanozeolite $(0,10$, and $30 \% \mathrm{w} / \mathrm{w})$, and incubation times (1, 5, 10, 20, 30, 45, 60, 75, and 90 days). Experimental data of MWD and OC fractions were subjected to analysis of variance and the means compared with the
Duncan's new multiple range test using SAS Ver.9.2 (SAS Institute 2008).

\section{Results and discussion}

Table 1 shows the sand, clay, and silt contents were 69,12 , and $19 \%$ in the studied soil, respectively. The soil texture was loamy sand. The soil was not saline (EC $1.1 \mathrm{dS} \mathrm{m}^{-1}$ ); equivalent calcium carbonate and $\mathrm{pH}$ values were $1.79 \%$ and 7.2, respectively, with low CEC $\left(4.80 \mathrm{Cmol} \mathrm{Kg}^{-1}\right)$ and Total OC $\left(3.41 \mathrm{~g} \mathrm{Kg}^{-1}\right)$.

Table 2 presents some properties of the applied plant residues. Alfalfa and wheat straw had a neutral $\mathrm{pH}(6$ and 7.97), high $\mathrm{OC}$ (511 and $532 \mathrm{~g} \mathrm{Kg}^{-1}$ ) values and $\mathrm{C} / \mathrm{N}$ (23.30 and 90.75) and $\mathrm{C} / \mathrm{P}(85.20$ and 123.50$)$ ratios, respectively. Some properties of applied nanozeolite and zeolite are shown (Table 3 ). The $\mathrm{pH}$ values in both the nanozeolite and zeolite are neutral, and nanozeolite and zeolite are not saline. CEC in nanozeolite is much higher than that in zeolite.

Table 4 shows the analysis of variance of the effects of nanozeolite, plant residues application, incubation time, and their interaction on MWDw and OC fractions in soil. Although the effects of applying nanozeolite, alfalfa, and wheat straws, their interaction, and incubation time on MWDw and OC fractions in soil were significant $(p<0.01)$, the interactions between nanozeolite and incubation time; plant residues and incubation time, and between nanozeolite, plant residues, and incubation time did not have significant effects on MWDw and OC fractions in the soil.

Table 5 shows the analysis of variance of the effects of zeolite and plant residues' application, incubation times, and their interactions on MWDw and OC fractions in soil. The effects of zeolite, alfalfa, and wheat straws

Table 1 Some chemical and physical properties of applied soil

\begin{tabular}{|c|c|c|c|c|c|c|c|}
\hline $\mathrm{EC}\left(\mathrm{dS} \mathrm{m} \mathrm{m}^{-1}\right)$ & $\mathrm{PH}$ & $\mathrm{CEC}\left(\mathrm{Cmol}+\mathrm{Kg}_{\text {soil }}^{-1}\right)$ & Total organic $\mathrm{C}\left(\mathrm{g} \mathrm{Kg}^{-1}\right)$ & $\begin{array}{l}\mathrm{CCE}^{\mathrm{a}} \\
\%\end{array}$ & Sand & Clay & $\overline{\text { Silt }}$ \\
\hline 1.1 & 7.2 & 4.80 & 3.41 & 1.79 & 69 & 12 & 19 \\
\hline
\end{tabular}

${ }^{a}$ Carbonate calcium equivalent

Table 2 Some physical and chemical properties of used plant residues in this study

\begin{tabular}{rlllllll}
\hline & PH & $\begin{array}{l}\text { EC } \\
\left(\mathrm{dS} \mathrm{m}^{-1}\right)\end{array}$ & $\begin{array}{l}\text { Total organic } \mathrm{C} \\
\left(\mathrm{g} \mathrm{Kg}^{-1}\right)\end{array}$ & $\begin{array}{l}\text { Total nitrogen } \\
\left(\mathrm{g} \mathrm{Kg}^{-1}\right)\end{array}$ & $\begin{array}{l}\text { Total phosphorous } \\
\left(\mathrm{g} \mathrm{Kg}^{-1}\right)\end{array}$ & $\mathrm{C} / \mathrm{N}$ & $\mathrm{C} / \mathrm{P}$ \\
\hline $\begin{array}{r}\text { Alfalfa } \\
\text { straw }\end{array}$ & 6 & 9.5 & 511 & 22 & 5.98 & 23.30 & 85.20 \\
$\begin{array}{r}\text { Wheat } \\
\text { straw }\end{array}$ & 7.97 & 4.3 & 532 & 7 & 4.31 & 90.75 & 123.50 \\
\hline
\end{tabular}


applications, their interactions, and incubation times on MWDw and OC fractions in soil were significant $(p<0.01)$. Also, the interactions between the application of zeolite and incubation time, plant residues and incubation time, and between zeolite and plant residues and incubation time did not have significant effects on MWDw and OC fractions in the soil.

Figure 1 shows Duncan's tests of means of MWDw and OC fractions in the soil as affected by nanozeolite, zeolite, alfalfa, and wheat straws percentages applied in the soil.

Table 3 Some properties of applied nanozeolite and zeolite

\begin{tabular}{lcc}
\hline Parameter & Nanozeolite & Zeolite \\
\hline $\mathrm{pH}$ & 7.17 & 7.20 \\
$\mathrm{EC}\left(\mathrm{dS} \mathrm{m}{ }^{-1}\right)$ & 0.98 & 1.20 \\
$\mathrm{CEC}\left(\mathrm{Cmol}+\mathrm{Kg}_{\text {soil }}^{-1}\right)$ & 400.39 & 169.3 \\
Total organic $\mathrm{C}\left(\mathrm{g} \mathrm{Kg}^{-1}\right)$ & 1.03 & 0.93 \\
\hline
\end{tabular}

MWDw increased by the addition of higher percentages of nanozeolite and zeolite (10 and $30 \%$ ) and $5 \%$ plant residues into the soil. The amounts of MWDw on the treated soil with $30 \%$ zeolitic materials and $5 \%$ plant residues increased by 0.735 and $0.685 \mathrm{~mm}$ in $30 \%$ nanozeolite plus $5 \%$ alfalfa straw (compound A), and $30 \%$ zeolite plus $5 \%$ alfalfa straw (compound B) compared with the control, respectively.

The highest amounts of MWDw were observed as 1.24 and $1.19 \mathrm{~mm}$ in compound $\mathrm{A}$ and compound $\mathrm{B}$, respectively. The comparison of treatments obtained, in mixed samples that applied nanozeolite, zeolite, and different plant residues, compound $\mathrm{A}$ was more effective than compound B (Fig. 1), because the amount of MWDw was higher in compound $\mathrm{A}$ into the compound $\mathrm{B}$.

Although MWDw is known to be related to soil aggregate stability, the results of recent researches indicated that the SOC is closely related to the formation and stability of soil aggregates (Tisdall and Oades 1982). Thus, the
Table 4 Analysis of variance (mean square) of the effects of nanozeolite and plant residues application, incubation time, and their interactions on MWDw and organic carbon fractions in soil

$n s$ Mean square of the treatment is not significant

** Mean square of the treatment is significant at the 0.01 level

Table 5 Analysis of variance (mean square) of the effects of zeolite, plant residues' application, incubation time, and their interactions on MWDw and organic carbon fractions in soil

$n s$ Mean square of the treatment is not significant

** Mean square of the treatment is significant at the 0.01 level

\begin{tabular}{|c|c|c|c|c|c|c|}
\hline \multirow[t]{2}{*}{ Source } & \multirow[t]{2}{*}{ DF } & \multirow{2}{*}{$\begin{array}{l}\text { MWDw } \\
(\mathrm{mm})\end{array}$} & \multicolumn{4}{|c|}{ Organic carbon $\left(\mathrm{g} \mathrm{Kg}_{\text {soil }}^{-1}\right)$} \\
\hline & & & $\begin{array}{l}\text { Agg. size } \\
>2 \mathrm{~mm}\end{array}$ & $\begin{array}{l}\text { Agg. size } \\
(1-2 \mathrm{~mm})\end{array}$ & $\begin{array}{l}\text { Agg. size } \\
(0.25-1 \mathrm{~mm})\end{array}$ & $\begin{array}{l}\text { Agg. size } \\
(0.053-0.25 \mathrm{~mm})\end{array}$ \\
\hline Nanozeolite & 2 & $9.7 * *$ & $52.28 * *$ & $46.97 * *$ & $40.03 * *$ & $27.79 * *$ \\
\hline Plant residues & 3 & $0.45 * *$ & $2.47 * *$ & $1.65 * *$ & $1.4^{* *}$ & $0.97 * *$ \\
\hline Time & 8 & $1.16 * *$ & $17.54 * *$ & $7.19 * *$ & $6.12 * *$ & $4.25 * *$ \\
\hline Nanozeolite $\times$ time & 16 & $1.10 \mathrm{~ns}$ & $9.76 \mathrm{~ns}$ & $5.82 \mathrm{~ns}$ & $4.96 \mathrm{~ns}$ & $3.44 \mathrm{~ns}$ \\
\hline Plant residues $\times$ time & 24 & $0.30 \mathrm{~ns}$ & $4.22 \mathrm{~ns}$ & $1.78 \mathrm{~ns}$ & $1.52 \mathrm{~ns}$ & $1.05 \mathrm{~ns}$ \\
\hline $\begin{array}{l}\text { Nanozeolite } \times \text { plant } \\
\text { residues }\end{array}$ & 6 & $1.88 * *$ & $10.21 * *$ & $9.01 * *$ & $7.68 * *$ & $5.33 * *$ \\
\hline $\begin{array}{l}\text { Nanozeolite } \times \text { plant } \\
\text { residues } \times \text { time }\end{array}$ & 48 & $0.28 \mathrm{~ns}$ & $2.44 \mathrm{~ns}$ & $1.46 \mathrm{~ns}$ & $1.24 \mathrm{~ns}$ & $0.86 \mathrm{~ns}$ \\
\hline Error & 216 & 0.003 & 0.001 & 0.002 & 0.0015 & 0.0011 \\
\hline
\end{tabular}

\begin{tabular}{|c|c|c|c|c|c|c|}
\hline \multirow[t]{2}{*}{ Source } & \multirow[t]{2}{*}{$\mathrm{DF}$} & \multirow{2}{*}{$\begin{array}{l}\text { MWDw } \\
(\mathrm{mm})\end{array}$} & \multicolumn{4}{|c|}{ Organic carbon $(\mathrm{g} / \mathrm{Kg}$ soil $)$} \\
\hline & & & $\begin{array}{l}\text { Agg. size } \\
>2 \mathrm{~mm}\end{array}$ & $\begin{array}{l}\text { Agg. size } \\
(1-2 \mathrm{~mm})\end{array}$ & $\begin{array}{l}\text { Agg. size } \\
(0.25-1 \mathrm{~mm})\end{array}$ & $\begin{array}{l}\text { Agg. size } \\
(0.053-0.25 \mathrm{~mm})\end{array}$ \\
\hline Zeolite & 2 & $7.03 * *$ & $27.85 * *$ & $20.91 * *$ & $17.82 * *$ & $13.37 * *$ \\
\hline Plant residues & 3 & $0.68 * *$ & $2.20 * *$ & $1.62 * *$ & $1.31 * *$ & $1.08 * *$ \\
\hline Time & 8 & $1.49 * *$ & $10.55^{* *}$ & $7.18^{* *}$ & $6.13 * *$ & $4.75 * *$ \\
\hline Zeolite $\times$ time & 16 & $1.002 \mathrm{~ns}$ & $5.40 \mathrm{~ns}$ & $3.82 \mathrm{~ns}$ & $3.25 \mathrm{~ns}$ & $2.26 \mathrm{~ns}$ \\
\hline $\begin{array}{l}\text { Plant } \\
\quad \text { residues } \times \text { time }\end{array}$ & 24 & $0.40 \mathrm{~ns}$ & $2.60 \mathrm{~ns}$ & $1.74 \mathrm{~ns}$ & $1.49 \mathrm{~ns}$ & $1.01 \mathrm{~ns}$ \\
\hline $\begin{array}{l}\text { Zeolite } \times \text { plant } \\
\text { residues }\end{array}$ & 6 & $1.47 * *$ & $5.7 * *$ & $4.27 * *$ & $3.64 * *$ & $2.52 * *$ \\
\hline $\begin{array}{l}\text { Zeolite } \times \text { plant } \\
\text { residues } \times \text { time }\end{array}$ & 48 & $0.26 \mathrm{~ns}$ & $1.37 \mathrm{~ns}$ & $0.97 \mathrm{~ns}$ & $0.83 \mathrm{~ns}$ & $0.67 \mathrm{~ns}$ \\
\hline Error & 216 & 0.0004 & 0.01 & 0.007 & 0.008 & 0.005 \\
\hline
\end{tabular}




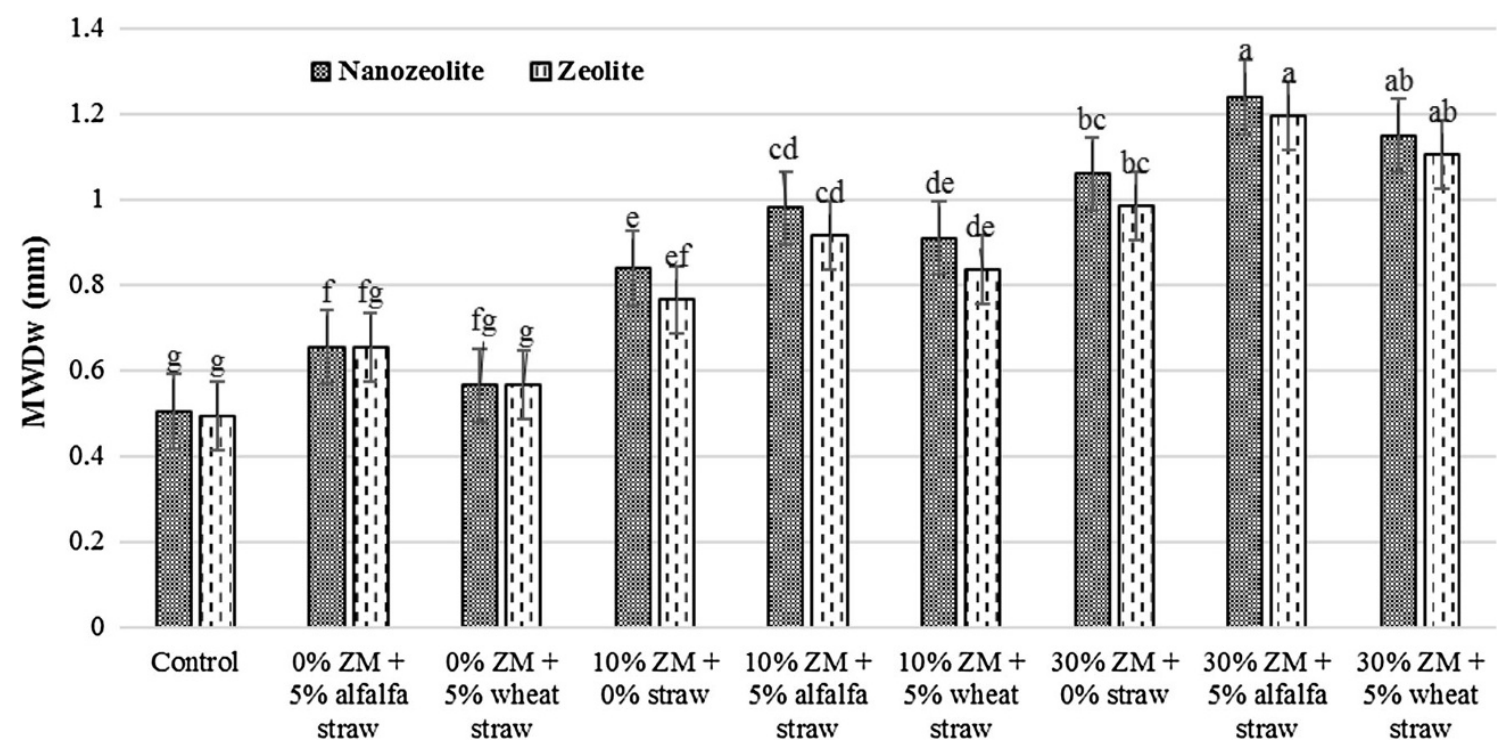

Fig. 1 Comparison of MWDw (mm) in treated soil by zeolitic materials (ZM) and plant residues

amendment of organic residues can improve soil structure and increase aggregate stability (Hati et al. 2008). Soil management systems that leave more plant residues on the soil surface generally allow for improvements in soil aggregation and aggregate stability (Carpenedo and Mielniczuk 1990).

Aggregate stability and SOC have also been shown to be positively correlated with polyphenol concentration (Griffiths and Burns 1972; Martens 2000, 2002; Martens and Loeffelmann 2002), which has been thought to be an important precursor of humic substances that stabilize aggregates (Dell'Agnola and Ferrari 1971; Stevenson 1994).

Blair et al. (2005) observed slower decomposition and greater aggregate stability (MWD) following the addition of intermediate quality Flemingia macrophylla ( $>4 \%$ polyphenols) versus the addition of high quality Medicago truncatula. The reason for the stability of the aggregate hierarchy is most probably the continuous incorporation of young organic matter (Puget et al. 2000; Six et al. 2000; Helfrich et al. 2008), like carbohydrates and glomalin-related soil protein (GRSP), which decreased less than the TOC.

Among the various components of SOM, carbohydrates have particular importance in increasing aggregate stability (Angers and Mehuys 1989; Feller and Beare 1997), and as such, may act to a certain degree in protecting soil organic carbon against mineralization.

It was suggested that, for instance, macroaggregates are stabilized mainly by carbohydrate-rich roots or plant debris occluded within aggregates (Golchin et al. 1995). Various authors have also observed the positive effects of long-term manure application on MWD (Singh et al. 2007; Su et al. 2006) and better physical condition of soil.
Nanozeolite and zeolite are clay minerals, and they have considerable calcium (Ca) content (Kazemian 2002). For this reason, greater concentration of $\mathrm{Ca}$, which acts as a potential cationic bridge between the inorganic and organic colloids' surfaces (Bronick and Lal 2005; Six et al. 2004). The availability of polyvalent cations, such as $\mathrm{Ca}^{2+}$, is an important factor in the chemical protection of TOC. In addition to its role as a binding agent, polyvalent cations enhance the formation of cationic bridges between organic matter and clay (Bronick and Lal 2005; Six et al. 2004); a high saturation of clay particles with these cations helps the organic-mineral complex to remain more flocculated and condensed as well as reducing the efficiency of microbial and enzymatic attacks (Baldock and Skjemstad 2000).

Calcium exerts an influence on organo-mineral complexation and its stability is observed mainly at the microaggregate level (Six et al. 2004). According to Baldock et al. (1994), the process of Ca bridge formation is the dominant factor in the positive long-term effect of the addition of $\mathrm{Ca}$ on the structural stability of the soil. Meanwhile, the results reported by Muneer and Oades (1989) provide support for an association between the highest content of TOC with liming, and increased availability of $\mathrm{Ca}^{2+}$. Those authors also concluded that the additions of $\mathrm{CaCO}_{3}$ and glucose result in the formation of macroaggregates larger than $2 \mathrm{~mm}$ in $80 \%$ of the soil, and only a small proportion of aggregates that are smaller than $0.05 \mathrm{~mm}$.

Briedis et al. (2012) reported that $\mathrm{Ca}^{2+}$ from the surface liming was positively correlated with the TOC content and acted as a cationic bridge between the clay particles' surfaces and the OC of the soil, contributing to the sequestration of carbon. Water-stability of soil aggregates has 
been reported to increase with revegetation in a landslide area (Burri et al. 2009).

Figure 2 shows the amounts of MWDw on the treated soil with nanozeolite, zeolite, and plant residues, increased significantly during the 90 days of incubation. The amount of MWDw on the treated soil with nanozeolite and plant residues was $0.65 \mathrm{~mm}$ at the start of incubation, which increased to $1.16 \mathrm{~mm}$ after 90 days of incubation. Also the amounts of MWDw on the treated soil with zeolite and plant residues increased from $0.58 \mathrm{~mm}$ on the $1 \mathrm{st}$ day of incubation to $1.1 \mathrm{~mm}$ on the 90th day of incubation. Also Fig. 2 reveals that the amounts of MWDw on treated soil with nanozeolite and plant residues were higher compared with those on treated soil with zeolite and plant residues. These changes were reasonably related to the OC variation in the soil.

Figure 3 shows that the amount of OC in all of aggregate size fractions increased significantly $(p<0.01)$ with the additions of nanozeolite, zeolite, and plant residues to the soil, especially that of alfalfa straw, into the control. The amounts of OC were significantly great with the addition of higher percentages of zeolitic materials (10 and $30 \%$ ), and plant residues (5\%), especially alfalfa straw, in all of the aggregate sizes, in both the compound $\mathrm{A}$ and the compound B treatments. However, the amounts of OC was higher in each aggregate size fraction in the treated soil with nanozeolite and alfalfa straw than that in the treated soil with zeolite and alfalfa straw (Fig. 3, 4, 5, 6).

The amount of OC increased from $2.16\left(\mathrm{~g} \mathrm{Kg}_{\text {soil }}^{-1}\right)$ in control to 3.93 and $3.54\left(\mathrm{~g} \mathrm{Kg}_{\text {soil }}^{-1}\right)$ in compound $\mathrm{A}$ and compound $\mathrm{B}$, respectively, in aggregate size fraction $(>2 \mathrm{~mm})$. Also, in this aggregate size class, the amounts of OC increased from $10 \%$ nanozeolite $3.27\left(\mathrm{~g} \mathrm{Kg}_{\text {soil }}^{-1}\right)$ and zeolite $2.91\left(\mathrm{~g} \mathrm{Kg}_{\text {soil }}^{-1}\right)$ in (10\% zeolitic materials plus $5 \%$ alfalfa straw) treatment to $30 \%$ nanozeolite $3.93\left(\mathrm{~g} \mathrm{Kg}_{\text {soil }}^{-1}\right)$ and zeolite $3.54\left(\mathrm{~g} \mathrm{Kg}_{\text {soil }}^{-1}\right)$ in $(30 \%$ zeolitic materials plus $5 \%$ alfalfa straw) treatment. The amount of OC in aggregate size fraction $(>2 \mathrm{~mm})$ increased with additions of $5 \%$ alfalfa straw 3.93 and $3.54\left(\mathrm{~g} \mathrm{Kg}_{\text {soil }}^{-1}\right)$ in $(30 \%$ zeolitic materials plus $5 \%$ alfalfa straw) treatment toward $5 \%$ wheat straw 3.69 and $3.31\left(\mathrm{~g} \mathrm{Kg}_{\text {soil }}^{-1}\right)$ in $(30 \%$ zeolitic materials plus $5 \%$ wheat straw) treatment in nanozeolite and zeolite, respectively.

The achieved results from previous researches showed that long-term field studies in the North America, and China indicate that manuring increases the SOC (Liu et al. 2003; Whalen and Chang 2002). In a 25-year study, SOC progressively increased with manure applications at an average rate of $0.181\left(\mathrm{~g} \mathrm{Kg}^{-1} \mathrm{mg}^{-1}\right)$ of manure (Hao et al. 2003). Management practices such as reduced tillage and increased $\mathrm{C}$ inputs through residue management and manuring improve soil structure, reduce erosion, $\mathrm{C}$ loss through mineralization, and $\mathrm{CO}_{2}$ emissions (Hao et al. 2002; Lal 2003a, 2003b).

Carpenedo and Mielniczuk (1990) reported a mediumto-high correlation between the geometric mean diameter (GMD), the MWD, the amount of aggregates $>2 \mathrm{~mm}$, and the TOC content of Latosols from Brazil; also another research achieved similar result of OC content of Latosols from Brazil (Castro Filho et al. 2002). Kouakoua et al. (1999) and Dutartre et al. (1993) indicated a strong correlation between aggregate stability in water and the carbon content of bulk clayey Ferralsols from Africa.

Figure 4 shows that the amount of OC increased with the additions of the higher percentages of nanozeolite, zeolite, and plant residues, particularly alfalfa straw, in aggregate size 1-2 $\mathrm{mm}$; in $\mathrm{A}$ and $\mathrm{B}$ compounds, $\mathrm{OC}$ was maximum compared with the control and other treatments. However, comparison of the OC contents in zeolitic materials showed that proportion of nanozeolite to the

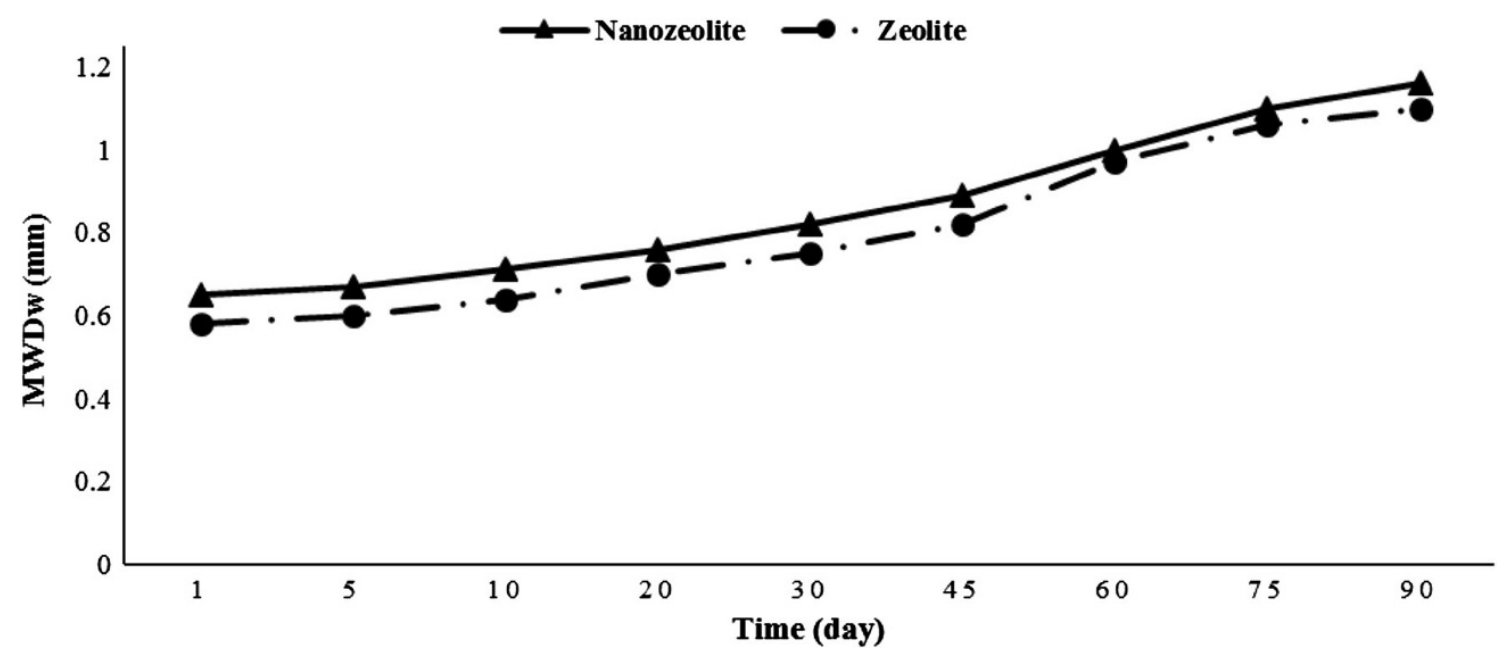

Fig. 2 The amounts of MWDw on the treated soil with nanozeolite, zeolite, and plant residues during 90 days of incubation 


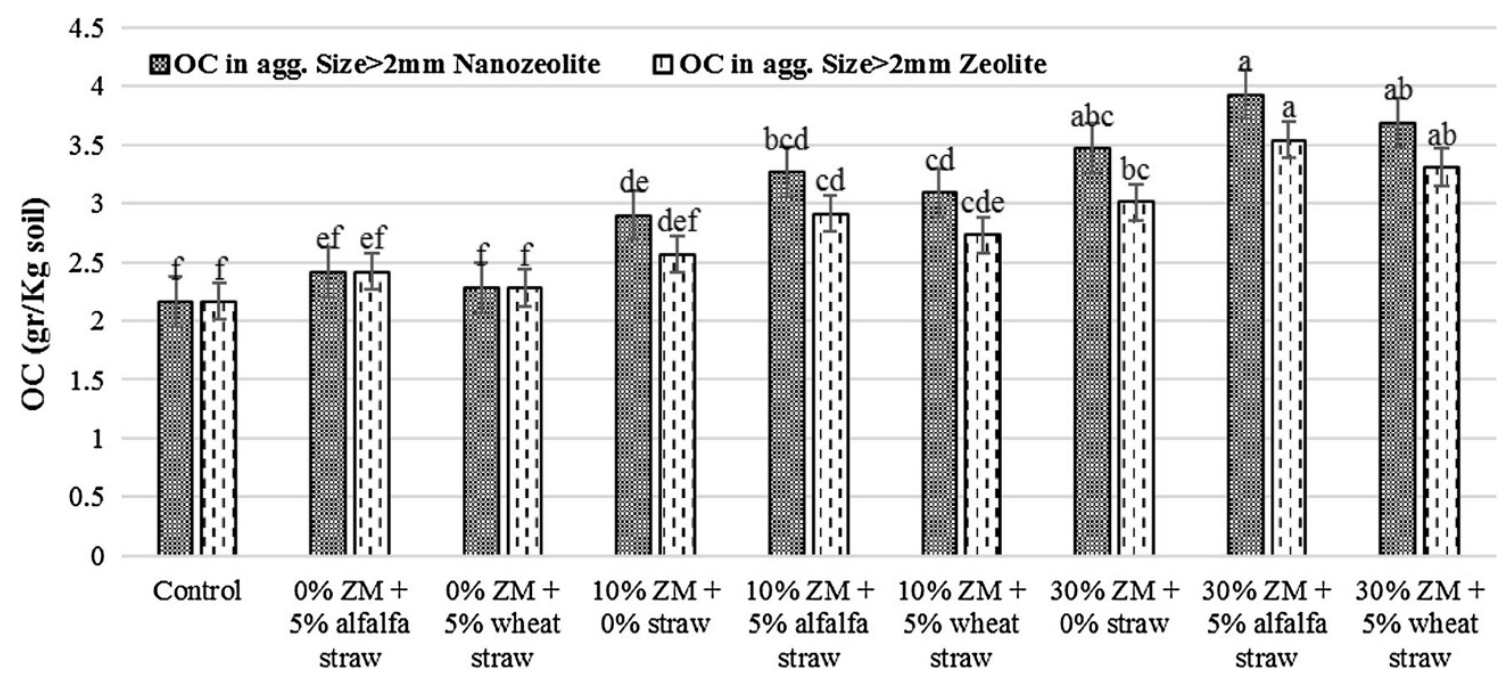

Fig. 3 Comparison of OC (g/Kg soil) in aggregate size $>2 \mathrm{~mm}$ in treated soil by zeolitic materials (ZM) and plant residues

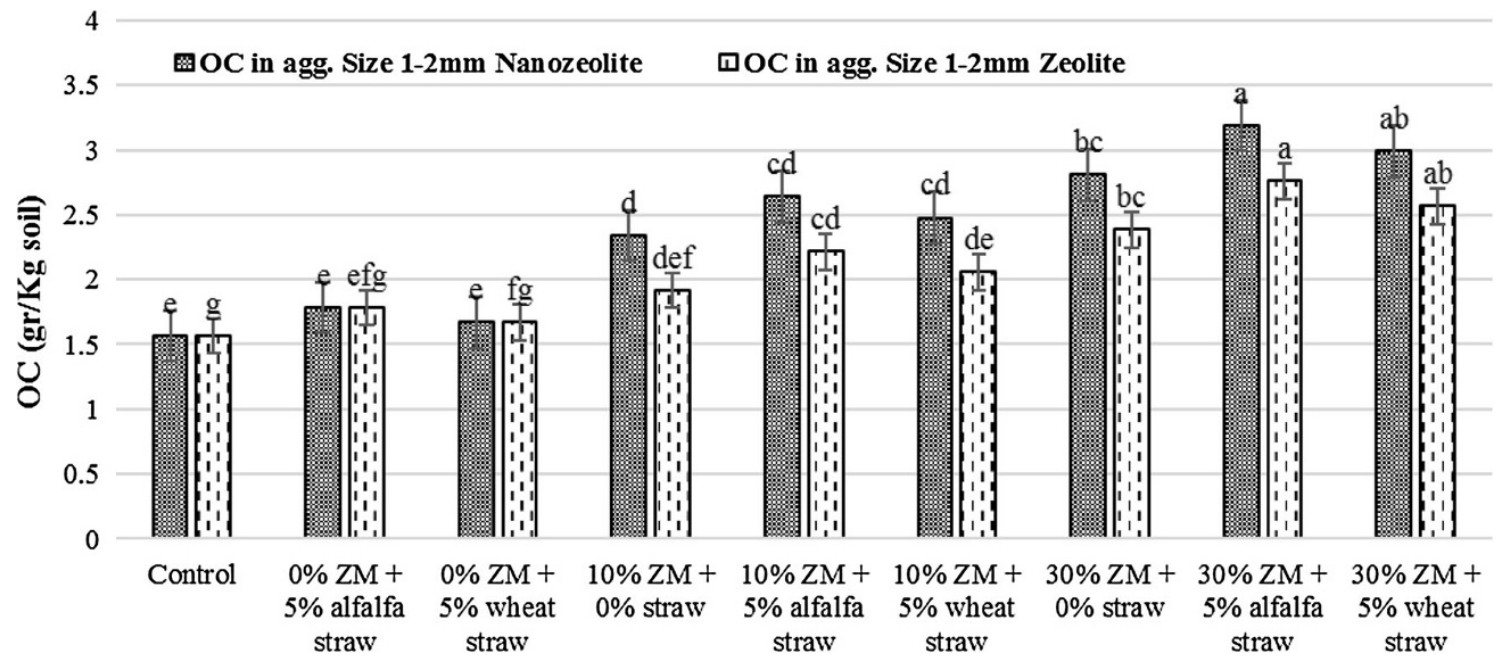

Fig. 4 Comparison of OC (g/Kg soil) in aggregate size (1-2) $\mathrm{mm}$ in treated soil by zeolitic materials (ZM) and plant residues

increasing amount of OC was greater than that of zeolite (Fig. 4).

The results showed the amount of OC increased in aggregate size range of $0.25-1 \mathrm{~mm}$ with the additions of nanozeolite and zeolite, especially nanozeolite, and also addition of plant residues, particularly alfalfa straw; the amounts of $\mathrm{OC}$ were 2.76 and $2.36\left(\mathrm{~g} \mathrm{Kg}_{\text {soil }}^{-1}\right)$ in compound $\mathrm{A}$ and compound B, respectively (Fig. 5). The results indicated that the amount of $\mathrm{OC}$ in aggregate size fraction $(0.053-0.25 \mathrm{~mm})$ increased with the additions of nanozeolite, zeolite, and plant residue. The amounts of OC were 2.2 and $1.87\left(\mathrm{~g} \mathrm{Kg}_{\text {soil }}^{-1}\right)$ in compound $\mathrm{A}$ and compound $\mathrm{B}$, respectively. However, comparison of zeolitic materials indicated that nanozeolite was more effective than zeolite for increasing the OC (Fig. 6).
In soils organic matter of which is acting as the major binding agent, $\mathrm{OC}$ concentrations may increase with the increasing aggregate size fractions, because larger aggregate size fractions are composed of smaller aggregates plus organic binding agents (Elliott 1986). TOC found in microaggregates is considered to be stabler and more resistant to microbial decomposition, leading to an accumulation of SOM over a long period (Angers et al. 1997; Oades 1984).

Microaggregates have been considered a key factor in the formation of new macroaggregates (Six et al. 2000) due to the protection of intra-aggregate TOC. The results revealed that larger aggregate size fractions had greater amount of OC than smaller aggregate size fractions. This may be due to either an increased aggregates' stability and strength caused by the addition of zeolitic materials, or 


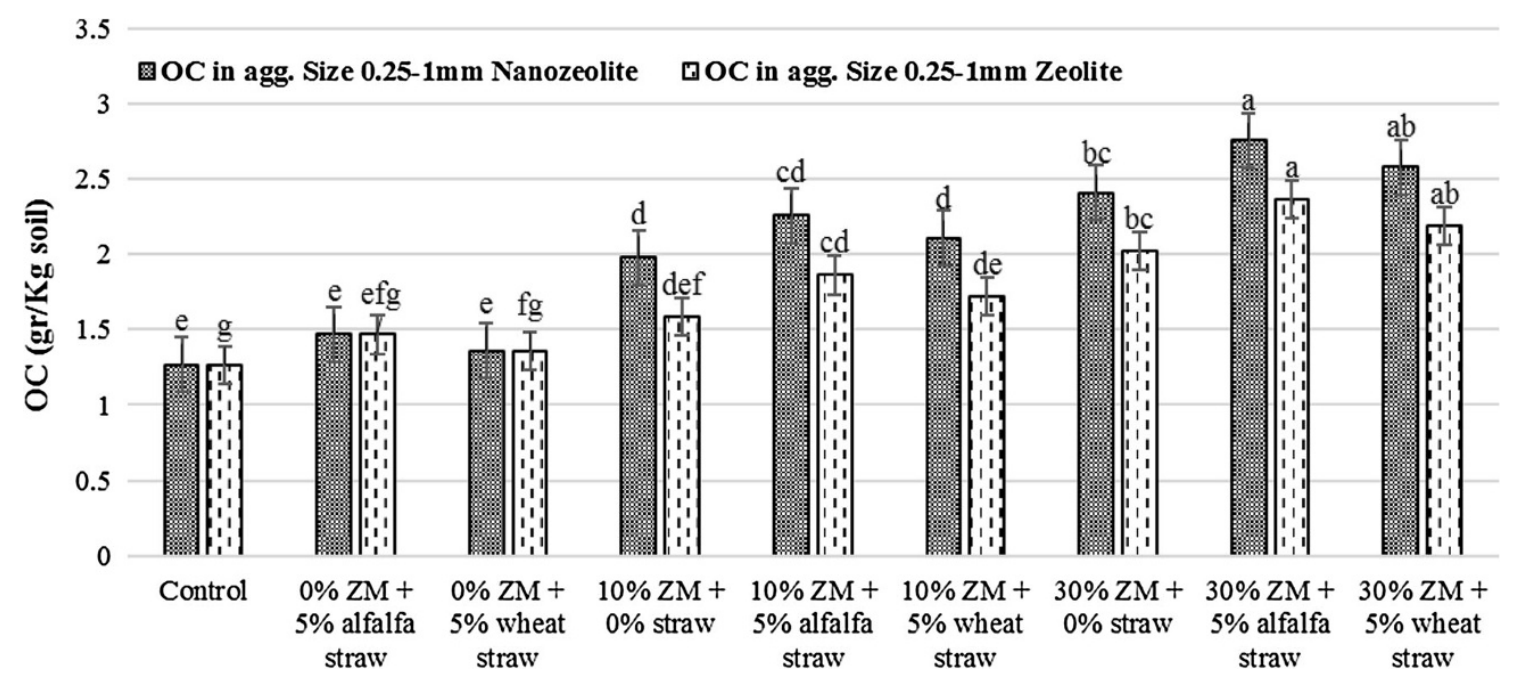

Fig. 5 Comparison of OC (g/Kg soil) in aggregate size $(0.25-1) \mathrm{mm}$ in treated soil by zeolitic materials (ZM) and plant residues

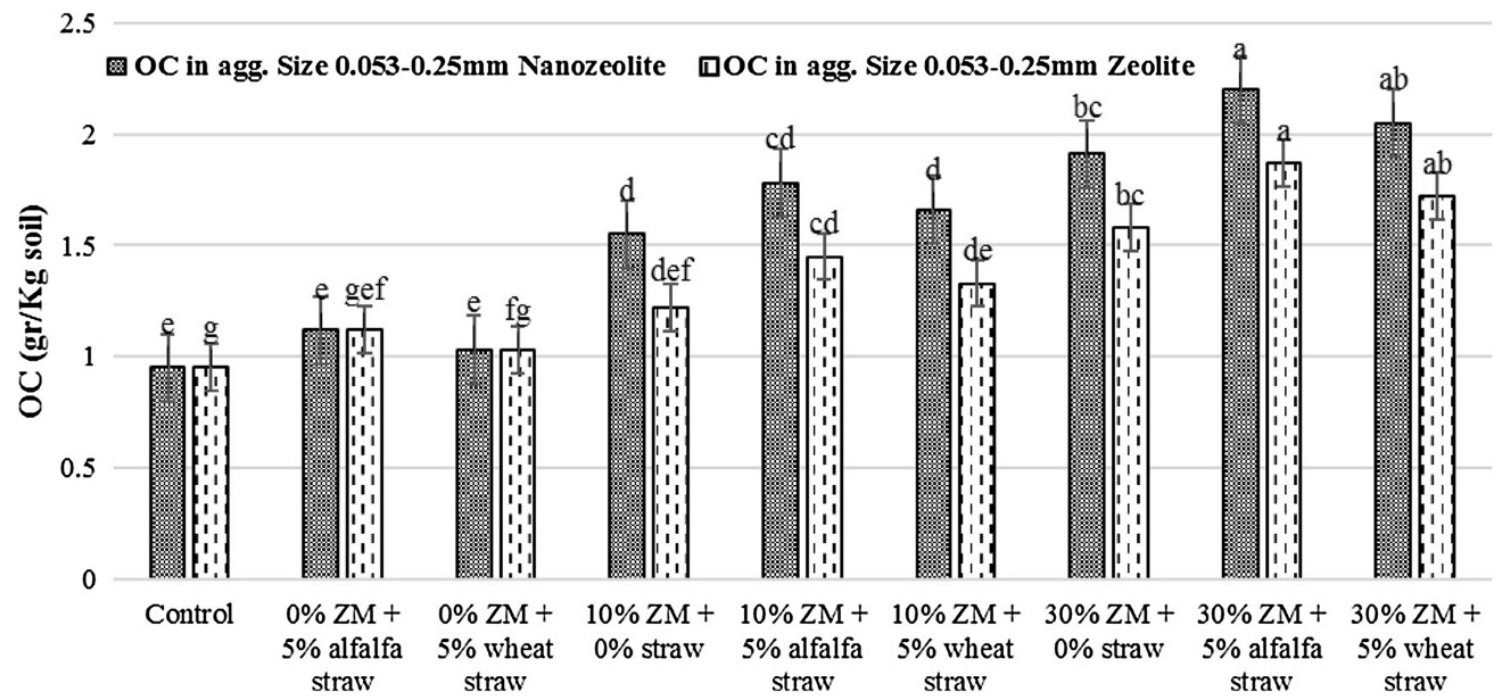

Fig. 6 Comparison of $\mathrm{OC}(\mathrm{g} / \mathrm{Kg}$ soil) in aggregate size $(0.053-0.25) \mathrm{mm}$ in treated soil by zeolitic materials (ZM) and plant residues

because the humification of plant residues increased the amount of $\mathrm{OC}$ in macroaggregates during incubation (Koushwaha et al. 2001) in the treated soil. Also Bronick and Lal (2005) concluded that smaller aggregates $(0.25-0.5 \mathrm{~mm})$ had smaller $\mathrm{C}$ aggregate compared with the larger aggregates.

Figure 7 reveals that the increased OC content of the treated soil during incubation in the lab condition. The $\mathrm{OC}$ content increased with the increasing time of incubation in different aggregate sizes $>2 \mathrm{~mm}$ (Fig. 7a), 1-2 mm (Fig. 7b), $0.25-1 \mathrm{~mm} \quad$ (Fig. 7c), and $0.053-0.25 \mathrm{~mm}$ (Fig. 7d). Overall, Fig. 7 indicates that the increasing OC content in the subsequent days of incubation in nanozeolite treatments were higher than that in zeolite treatments in all the aggregate size fractions. The amount of OC in larger aggregate size fractions was higher than that in smaller size fractions.

The manure which was applied for 2 years increased the SOC mineralization with the passage of time in different aggregate sizes (Pare et al. 2000; Aulakh et al. 2000). Aoyama and Kumakura (2001) investigated an increase in SOM with animal manure application, and consequently, the formation of macroaggregates $(250-1,000 \mu \mathrm{m})$. They further pointed out that manure application increased the accumulation of macroaggregate-protected $\mathrm{C}$ and thus sequestrated more organic $\mathrm{C}$ in soils.

Organic and inorganic fertilizers have complex effects on soil's physical, chemical, and biological properties, resulting in variable effects on soil aggregation (Bronick and Lal 2005). Also those authors reported that application 
Fig. 7 The amount of OC (g/

$\mathrm{Kg}$ soil) in a aggregate size

$>2 \mathrm{~mm}, \mathbf{b}$ aggregate size $(1-2)$

$\mathrm{mm}$, c aggregate size $(0.25-1)$

$\mathrm{mm}$, and $\mathbf{d}$ in aggregate size

$(0.053-0.25) \mathrm{mm}$, on the treated

soil with nanozeolite, zeolite,

and plant residues during

90 days of incubation a
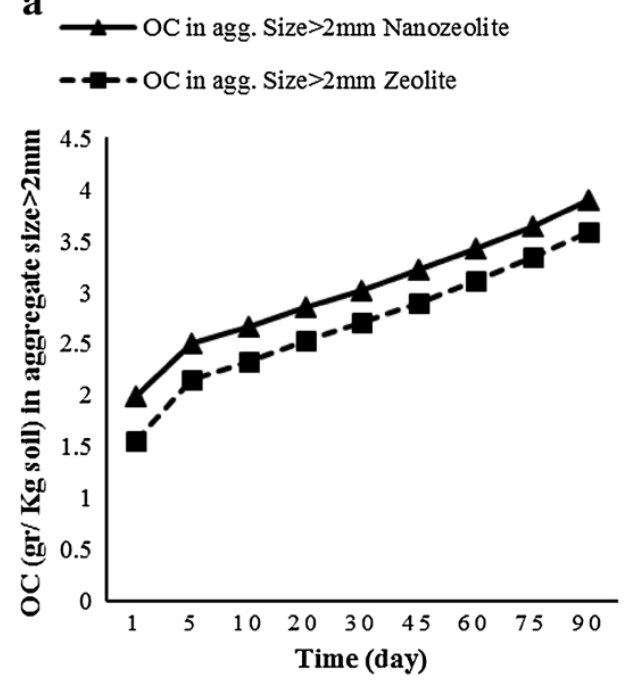

c

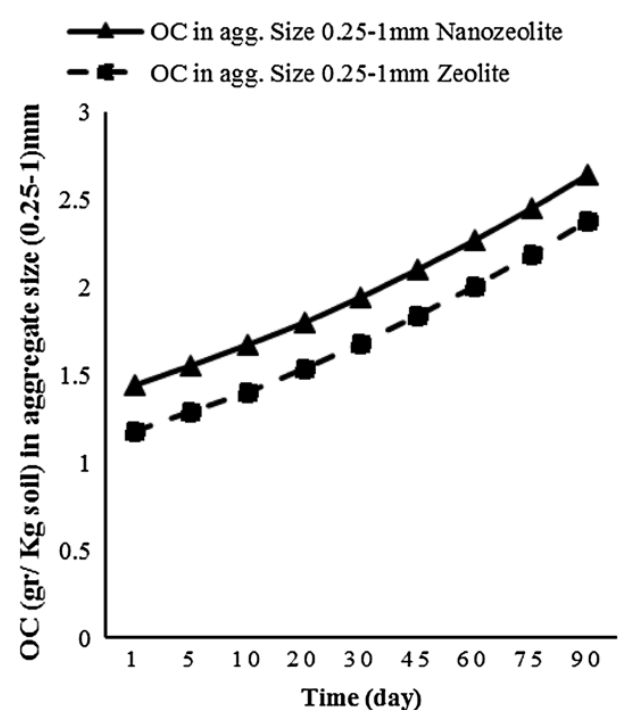

b
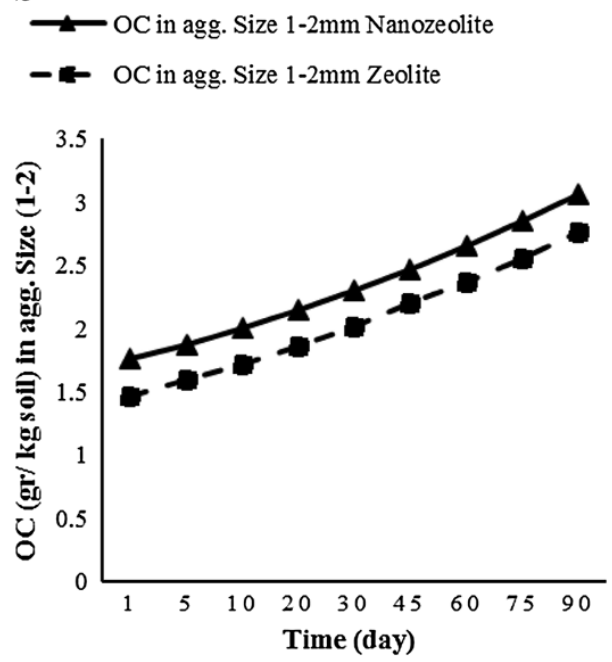

d

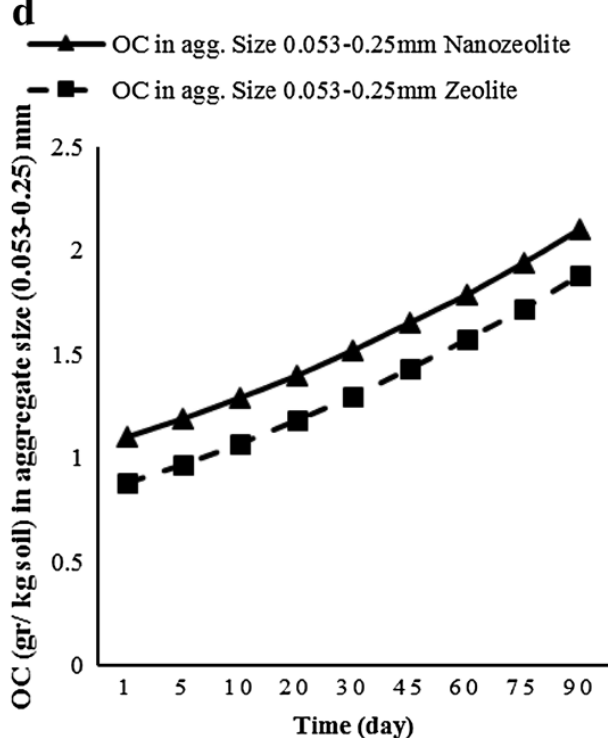

of organic manure directly increases SOM, leading to improved soil aggregation and enhanced stability over time. These trends are usually indicated by increases in macroaggregate content and the MWDw, as well as by decreases in bulk density (Bronick and Lal 2005; Haynes and Naidu 1998; Sainju et al. 2003; Whalen and Chang 2002).

Huang et al. (2010) observed significantly more macroaggregates and higher SOM content in the bulk soil and the $>2 \mathrm{~mm}$ aggregate fraction for the NPK plus OM treatment compared with the other treatments. Zhou et al. (2013) concluded that the application of NPK plus OM increased the size of sub-aggregates that comprised the macroaggregates. Also, they observed that long-term application of NPK plus OM improves soil aggregation and alters the three-dimensional microstructure of macroaggregates, while NPK alone does not. In other research studies, it was reported that the enrichment of the SOC, either from crop residues or from directly applied organic manure, has been documented to improve soil aggregation (Six et al. 1998, 2004).

Chen and Shrestha (2012) observed that the SOC increased with the passage of time (year) and caused an increase in percentage of water-stable aggregate. Higher $\mathrm{C}$ accumulation in macroaggregates could be due to the lower decomposable SOM associated with these aggregates and also the direct contribution of SOM to the stability of macroaggregates resulting in only C-rich macroaggregates being able to withstand slaking due to zeolitic materials in the soil. The achieved results from the present study are in accordance with the results of Tripathi et al. (2014). 


\section{Conclusion}

Aggregation process in the soil is important, and it plays a considerable role in improving the soil physical characteristics such as hydraulic conductivity, infiltration, ventilation, etc. Also, the aggregation process is important in improving the carbon sequestration in soil. This report shows the effects of application of nanozeolite and zeolite on MWDw as an index of aggregate stability and strength, and OC aggregate size fractions in a soil treated with some plant residues during the incubation period. The results revealed that the amount of MWDw increased with the additions of nanozeolite, zeolite, and plant residues.

The highest amount of MWDw was measured when $30 \%$ zeolitic materials and $5 \%$ plant residues were added to the soil. The results showed that nanozeolite was more effective in increasing the OC contents in MWDw than zeolite. Also alfalfa straw efficiently produced more OC than wheat straw did. In other words, higher percentages of nanozeolite, zeolite, and plant residues increased the amount of MWDw in treated soils. During the incubation period, MWDw increased from the first day until the 90th day of incubation.

The highest amounts of $\mathrm{OC}$ were found in compound $\mathrm{A}$ and compound $\mathrm{B}$ treatments in all the aggregate size fractions. However, comparison of OC contents in zeolitic materials showed that nanozeolite plays an important role in increasing the OC contents in different aggregate size fractions compared with the zeolite. Also the amount of $\mathrm{OC}$ in larger aggregates size fractions was higher than that in smaller fractions. The amount of OC increased with the increasing time of incubation in different aggregates size fractions. Thus, the highest amount of OC was measured in soil treated by compound A. This compound can be more effective to improve soil carbon sequestration. However, it must be mentioned that additional and more researches need for the assessing of the effects of zeolitic materials, plant residues, and their interactions on $\mathrm{OC}$ fractions and other characteristics of soil under different incubation conditions.

Acknowledgments The authors sincerely thank the editor and the anonymous reviewers for reviewing the manuscript and providing critical comments to improve the paper. They also offer many thanks to the Fadak institute in Isfahan and the Afrazand factory in Tehran.

Open Access This article is distributed under the terms of the Creative Commons Attribution License which permits any use, distribution, and reproduction in any medium, provided the original author(s) and the source are credited.

\section{References}

Abdi GH, Khui MK, Eshghi S (2006) Effects on natural zeolite on growth and flowering on straw berry. Int $\mathrm{J}$ Agric Resour $1: 384-389$
Angers DA (1992) Changes in soil aggregation and organic carbon under corn and alfalfa. Soil Sci Soc Am J 56:1244-1249

Angers DA, Mehuys GR (1989) Effects of cropping on carbohydrate content and water-stable aggregation of a clay soil. Can J Soil Sci 69:373-380

Angers DA, Recous S, Aita C (1997) Fate of carbon and nitrogen in water-stable aggregates during decomposition of ${ }^{13} \mathrm{C}{ }^{15} \mathrm{~N}$-labeled wheat straw in situ. Eur J Soil Sci 48:295-300

Aoyama M, Kumakura N (2001) Quantitative and qualitative changes of organic matter in an ando soil induced by mineral fertilizer and cattle manure application for 20 years. Soil Sci Plant Nutr 47:241-252

Aulakh MS, Khera TS, Doran JW (2000) Mineralization and denitrification in upland, nearly saturated and flooded subtropical soil-II. Effect of organic manures varying in $\mathrm{N}$ content and C:N ratio. Biol Fertil Soils 31:168-174

Baldock JA, Skjemstad JO (2000) Role of the soil matrix and minerals in protecting natural organic materials against biological attack. Org Geochem 31:697-710

Baldock JA, Aoyanna M, Oades JM, Grant CD (1994) Structural amelioration of a South Australian red-brown earth using calcium and organic amendments. Aust J Soil Res 32:571-594

Beare MH, Cabrera ML, Hendrix PF, Coleman DC (1994) Aggregate protected and unprotected organic matter pools in conventional and no-tillage soils. Soil Sci Soc Am J 58:787-795

Blair N, Faulkner RD, Till AR, Sanchez P (2005) Decomposition of ${ }^{13} \mathrm{C}$ and ${ }^{15} \mathrm{~N}$ labelled plant residue materials in two different soil types and its impact on soil carbon, nitrogen and aggregate stability, and aggregate formation. Aust J Soil Res 43:873-886

Blanco-Canqui H, Lal R (2004) Mechanisms of carbon sequestration in soil aggregates. Crit Rev Plant Sci 23:481-504

Briedis C, MoraesSá JC, Fávero Caires E, Navarro JF, Inagaki TM, Boer A, Neto CQ, Oliveira Ferreira A, Canalli LB, Burkner dos Santos J (2012) Soil organic matter pools and carbon-protection mechanisms in aggregate fractions influenced by surface liming in a no-till system. Geoderma 170:80-88

Bronick CJ, Lal R (2005) Soil structure and management: a review. Geoderma 124:3-22

Burri K, Graf F, Böll A (2009) Revegetation measures improve soil aggregate stability: a case study on a landslide area in Central Switzerland. FOSNOLA 82:45-60

Carpenedo V, Mielniczuk J (1990) Estado de agregação e qualidade de agregados de LatossolosRoxos, submetidos a diferentessistemas de manejo. R Bras Ci Solo 14:99-105

Carpenter-Boggs L, Kennedy AC, Reganold JP (2000) Organic and biodynamic management: effects on soil biology. Soil Sci Soc Am J 54:1651-1659

Carter MR, Angers DA, Gregorich EG, Bolinder MA (2003) Characterizing organic matter retention for surface soils in eastern Canada using density and particle size fractionations. Can J Soil Sci 83:11-23

Castro Filho C, Lourenco A, Guimaraes MDF, Fonseca ICB (2002) Aggregate stability under different soil management systems in a red latosol in the state of Parana. Braz Soil Tillage Res 65:45-51

Chen HYH, Shrestha BM (2012) Stand age, fire and clearcutting affect soil organic carbon and aggregation of mineral soils in boreal forests. Soil Biol Biochem 50:149-157

Chivenge P, Vanlauwe B, Gentile R, Six J (2011) Organic resource quality influences short-term aggregate dynamics and soil organic carbon and nitrogen accumulation. Soil Biol Biochem 43:657-666

Christensen BT (2001) Physical fractionation of soil and structural and functional complexity in organic matter turnover. Eur J Soil Sci 52:345-353

Dell'Agnola G, Ferrari G (1971) Molecular sizes and functional groups of humic substances extracted by $0.1 \mathrm{M}$ pyrophosphate 
from soil aggregates of different stability. Eur J Soil Sci 22:342-349

Dutartre Ph, Bartoli F, Andreux F, Portal JM, Ange A (1993) Influence of content and nature of organic matter on the structure of some sandy soils from West Africa. In: Brussaard L, Kooistra MJ (eds) Proceedings of the international workshop on methods of research on soil structure/soil biota interrelationships vol 56 . Geoderma, p 459-478

Elliott ET (1986) Aggregate structure and carbon, nitrogen and phosphorus in native and cultivated soils. Soil Sci Soc Am J 50:627-633

Feller C, Beare MH (1997) Physical control of soil organic matter dynamics in the tropics. Geoderma 79:69-116

Golchin A, Oades JM, Skjemstad JO, Clark P (1995) Structural and dynamic properties of soil organic matter as reflected by ${ }^{13} \mathrm{C}$ natural abundance, pyrolysis mass spectrometry and solid-state ${ }^{13} \mathrm{C}$ NMR spectroscopy in density fractions of an oxisol under forest and pasture. Aust J Soil Res 33:59-76

Griffiths E, Burns RG (1972) Interaction between phenolic substances and microbial polysaccharides in soil aggregation. Plant Soil 36:599-612

Gupta VVSR, Germida JJ (1988) Distribution of microbial biomass and its activity in different soil aggregate size fractions as affected by cultivation. Soil Biol Biochem 20:777-786

Hao Y, Lal R, Owens LB, Izaurralde RC, Post WM, Hothem DL (2002) Effect of cropland management and slope position on soils organic carbon pool at the Appalachian experimental watersheds. Soil Tillage Res 68:133-142

Hao XY, Chang C, Travis GR, Zhang FR (2003) Soil carbon and nitrogen response to 25 annual cattle manure applications. J Plant Nutr Soil Sci 166:239-245

Hati KM, Swarup A, Mishra B, Manna MC, Wanjari RH, Mandal KG, Misra AK (2008) Impact of long-term application of fertilizer, manure and lime under intensive cropping on physical properties and organic carbon content of an alfisol. Geoderma 148:173-179

Haynes RJ, Naidu R (1998) Influence of lime, fertilizer and manure applications on soil organic matter content and soil physical conditions: a review. Nutr Cycl Agroecosyst 51:123-137

Haynes RJ, Swift RS (1990) Stability of soil aggregates in relation to organic constituents and soil water content. J Soil Sci 41:73-83

Helfrich M, Ludwig B, Potthoff M, Flessa H (2008) Effect of litter quality and soil fungi on macroaggregate dynamics and associated partitioning of litter carbon and nitrogen. Soil Biol Biochem 40:1823-1835

Hillel D (1982) Introduction to soil physics, vol 364. Academic Press, San Diego

Hinds A, Lowe LE (1980) Ammonium-N determination soil nitrogen Berthelot reaction. Soil Sci Plant Anal 11:469-475

Huang S, Peng X, Huang Q, Zhang W (2010) Soil aggregation and organic carbon fractions affected by long-term fertilization in a red soil of subtropical China. Geoderma 154:364-369

Kazemian H (2002) Zeolite science in Iran: a brief review. International conference on the occurrence, properties and utilization of natural zeolites. Greece, p 162-164

Kemper WD, Rosenau RC (1986) Aggregate stability and size distribution. In: Klute A (ed) Methods of soil analysis, Part I, physical and mineralogical methods. American Society of Agronomy, Madison

Kouakoua E, Larré-Larrouy MC, Barthès B, Freitas PL, Neves C, Sala GH, Feller C (1999) Relations entre stabilité de l'agrégationetmatiéreorganiqetotaleet soluble à l'eauchaudedans des sols ferrallitiquesargileux (Congo, Brésil). Can J Soil Sci 79(4):561-569

Koushwaha CP, Tripathi SK, Singh KP (2001) Soil organic matter and water-stable aggregates under different tillage and residue conditions in a tropical drylandagroecosystem. Appl Soil Ecol $16: 229-241$

Laganière J, Angers DA, Paré D, Bergeron Y, Chen HYH (2011) Black spruce soils accumulate more uncomplexed organic matter than aspen soils. Soil Sci Soc Am J 75:1125-1132

Lal R (2003a) Soil erosion and the global carbon budget. Environ Int 29:437-450

Lal R (2003b) Offsetting global $\mathrm{CO}_{2}$ emissions by restoration of degraded soils and intensification of world agriculture and forestry. Land Degrad Deviat 14:309-322

Liu XB, Han XZ, Song CY, Herbert SJ, Xing BS (2003) Soil organic carbon dynamics in black soils of China under different agricultural management systems. Community Soil Sci Plant Anal 34:973-984

Malik A, Scullion J (1998) Soil development on restored opencast coal sites with particular reference to organic matter and aggregate stability. Soil Usage Manage 14:234-239

Martens DA (2000) Management and crop residue influence soil aggregate stability. J Environ Qual 29:723-727

Martens DA (2002) Relationship between plant phenolic acids released during soil mineralization and aggregate stabilization. Soil Sci Soc Am J 66:1857-1867

Martens DA, Loeffelmann KL (2002) Improved accounting of carbohydrate carbon from plants and soils. Soil Biol Biochem 34:1393-1399

Muneer M, Oades JM (1989) The role of Ca-organic interactions in soil aggregate stability. III. Mechanisms and models. Aust J Soil Res 27:411-423

Oades JM (1984) Soil organic matter and structural stability mechanisms and implications for management. Plant Soil 76:319-337

Oades JM (1988) The retention of organic-matter in soils. Biogeochemistry 5:35-70

Pachepsky YA, Rawls WJ (2003) Soil structure and pedotransfer functions. Eur J Soil Sci 54:443-452

Pare T, Dinel H, Schnitzer M (2000) Carbon and nitrogen mineralization in soil amended with non-tabletized and tabletized poultry manure. Can J Soil Sci 80:271-276

Paul EA, Clark FE (1996) Soil microbiology and biochemistry. Academic Press, San Diego

Peperzak P, Caldwell AG, Hunziker R, Black CA (1959) Phosphorus fractions in manures. Soil Sci 87:293-302

Piccolo GA, Galantini JA, Rosell RA (2004) Organic carbon fractions in a yerba mate plantation on a subtropical Kandihumult of Argentina. Geoderma 123:333-341

Pikul JJL, Osborne S, Ellsbury M, Riedell W (2007) Particulate organic matter and water-stable aggregation of soil under contrasting management. Soil Sci Soc Am J 71:766-776

Pratt PF (1965) Potassium. In: Black CA (ed) Methods of soil analysis: Part 2. Chemical and microbiological properties. American Society of Agronomy, Madison, pp 1022-1030

Puget P, Chenu C, Balesdent J (2000) Dynamics of soil organic matter associated with particle-size fractions of water-stable aggregates. Eur J Soil Sci 51:595-605

Sainju U, Whitehead W, Singh B (2003) Cover crops and nitrogen fertilization effects on soil aggregation and carbon and nitrogen pools. Can J Soil Sci 83:155-165

SAS Institute (2008) SAS procedures guide. Version 9.2, SAS Institute, Cary

Shiralipour A, Mc Connell W, Smith WH (1992) Physical and chemical properties of soil as affected by municipal solid waste compost application. Biomass Bioenergy 3:195-211

Shukla MK, Lal R, Ebinger M (2004) Soil quality indicators for reclaimed mine soils in southeastern Ohio. Soil Sci 169:133-142

Singh G, Jalota SK, Singh Y (2007) Manuring and residue management effects on physical properties of a soil under the rice-wheat system in Punjab, India. Soil Tillage Res 94:229-238 
Six J, Elliott ET, Paustian K, Doran JW (1998) Aggregation and soil organic matter accumulation in cultivated and native grassland soils. Soil Sci Soc Am J 62:1367-1377

Six J, Paustian K, Elliot ET, Combrink C (2000) Soil structure and organic matter: I. Distribution of aggregate-size fractions and aggregate-associated carbon. Soil Sci Soc Am J 64:681-689

Six J, Conant RT, Paul EA, Paustian K (2002) Stabilization mechanisms of soil organic matter: implication for C-saturation of soils. Plant Soil 241:155-176

Six J, Bossuyt H, Degryze S, Denef K (2004) A history of research on the link between (micro) aggregates, soil biota, and soil organic matter dynamics. Soil Tillage Res 79:7-31

Spaccini R, Piccolo A, Conte P, Haberhauer G, Gerzabek MH (2002) Increased soil organic carbon sequestration through hydrophobic protection by humic substances. Soil Biol Biochem 34:1839-1851

Stevenson FI (1994) Characterization of soil organic matter by NMR spectroscopy and analytical pyrolysis. Humus chemistry, genesis composition reaction. Willey, New York, pp 259-284

Su YZ, Wang F, Suo DR, Zhang ZH, Du MW (2006) Long-term effect of fertilizer and manure application on soil-carbon sequestration and soil fertility under the wheat-wheat-maize cropping system in northwest China. Nutr Cycl Agroecosyst 75:285-295

Tisdall JM, Oades JM (1982) Organic matter and water-stable aggregates in soils. J Soil Sci 33:141-163

Tripathi R, Nayak AK, Bhattacharyya P, Shukla AK, Shahid M, Raja R, Panda BB, Mohanty S, Kumar A, Thilagam VK (2014) Soil aggregation and distribution of carbon and nitrogen in different fractions after 41 years long-term fertilizer experiment in tropical rice-rice system. Geoderma 213:280-286
Valmis S, Dimoyannis D, Danalatos NG (2005) Assessing interrill erosion rate from soil aggregate instability index, rainfall intensity and slope angle on cultivated soils in central Greece. Soil Tillage Res 80:139-147

Von Lützow M, Koegel-Knabner I, Ekschmitt K, Matzner E, Guggenberger G, Marschner B, Flessa H (2006) Stabilization of organic matter in temperate soils: mechanisms and their relevance under different soil conditions-a review. Eur J Soil Sci 57:426-445

Walkley A, Black IA (1934) An examination of digestion method for determining soil organic matter and a proposed modification of the chromic acid titration. Soil Sci 37:29-38

Wander MM, Bidart MG (2000) Tillage practice influences on the physical protection, bioavailability and composition of particulate organic matter. Biol Fertil Soils 32:360-367

Whalen JK, Chang C (2002) Macroaggregate characteristics in cultivated soils after 25 annual manure applications. Soil Sci Soc Am J 66:1637-1647

Yamashita T, Flessa H, John B, Helfrich M, Ludwig B (2006) Organic matter in density fractions of water-stable aggregate in silty soils: effect of land use. Soil Biol Biochem 38:3222-3234

Yoo G, Wander MM (2008) Tillage effects on aggregate turnover and sequestration of particulate and humified soil organic carbon. Soil Sci Soc Am J 72:670-676

Zhou H, Peng X, Perfect E, Xiao T, Peng G (2013) Effects of organic and inorganic fertilization on soil aggregation in an ultisol as characterized by synchrotron based X-ray micro-computed tomography. Geoderma 195-196:23-30 